University of Wollongong

Research Online

Faculty of Law, Humanities and the Arts Papers (Archive)

Faculty of Arts, Social Sciences \& Humanities

$1-1-2019$

Language and attitude shift of young Mauritians in secondary education

Anu Bissoonauth-Bedford

University of Wollongong, anu@uow.edu.au

Follow this and additional works at: https://ro.uow.edu.au/lhapapers

Part of the Arts and Humanities Commons, and the Law Commons

Research Online is the open access institutional repository for the University of Wollongong. For further information contact the UOW Library: research-pubs@uow.edu.au 


\title{
Language and attitude shift of young Mauritians in secondary education
}

\begin{abstract}
This study investigated the changing patterns of language use and language attitudes of younger generations of Mauritians over the last two decades. This article discusses the shift in language attitudes of students in secondary education with special emphasis on Kreol*, taught since 2012 in primary schools and from 2018 in secondary schools. A comparison with results from earlier studies suggests a positive attitude shift towards Kreol in education as well as an acceptance of multilingualism and multiculturalism as an integral part of being Mauritian. Asian heritage languages lag behind in the multidiglossic patterns of language use. Nonetheless, despite a steady decline in the home domain, students choose to study them in schools and attitudes towards them highlight a strong sense of cultural and religious attachment to ancestral heritage. *The word Kreol refers to Mauritian Creole. The term Creole is used to refer to the type of language and members of the Creole community, who are descendants of former slaves and mixed parentage.

Disciplines

Arts and Humanities | Law

Publication Details

Bissoonauth-Bedford, A. (2019). Language and attitude shift of young Mauritians in secondary education. Journal of Multilingual and Multicultural Development, Online First 1-15.
\end{abstract}

This journal article is available at Research Online: https://ro.uow.edu.au/lhapapers/4028 


\title{
Language and attitude shift of young Mauritians in secondary education
}

\author{
Anu Bissoonauth \\ Faculty of Law, Humanities and the Arts, University of Wollongong, Australia \\ Email:anu@uow.edu.au
}

\section{Abstract}

This study investigated the changing patterns of language use and language attitudes of younger generations of Mauritians over the last two decades. This article discusses the shift in language attitudes of students in secondary education with special emphasis on Kreol*, taught since 2012 in primary schools and from 2018 in secondary schools. A comparison with results from earlier studies suggests a positive attitude shift towards Kreol in education as well as an acceptance of multilingualism and multiculturalism as an integral part of being Mauritian. Asian heritage languages lag behind in the multi-diglossic patterns of language use. Nonetheless, despite a steady decline in the home domain, students choose to study them in schools and attitudes towards them highlight a strong sense of cultural and religious attachment to ancestral heritage.

*The word Kreol refers to Mauritian Creole. The term Creole is used to refer to the type of language and members of the Creole community, who are descendants of former slaves and mixed parentage.

Key words: multilingualism, education, Kreol, heritage language, language attitudes

\section{Introduction}

The language ecology in Mauritius is complex and intricate resulting from its colonial history and fifty years of independence since 1968. English is the de jure official language of government institutions, administration and the education system (Corne, 1999: 165), but in practice is more a written than a spoken language. French, on the other hand, is a vehicular language dominant in the workplace, media and education. A French-based Creole, (known as Kreol) is the lingua franca as well as the vernacular of $87 \%$ of the population according to the 2011 census. However, it does not have official status.

Twelve Asian languages listed as 'language of forefathers' in the last census carried out in 2011 are also currently spoken. The term 'language of forefathers' used in the national census refers to languages spoken by the immigrants when they first arrived in Mauritius. Although the concept of ancestral languages may be perceived as a constructed political ideology (Hookoomsing, 1986; Eisenlohr, 2006b, 2007; Rajah-Carrim, 
2005), in this article the terminology of ancestral languages is taken from Mufwene (2008a, 2008b) who uses 'heritage' and 'ancestral' to refer to languages spoken by the forefathers. The term ancestral language and heritage language are used interchangeably in this article.

Since the 1980s, the language education policy of successive Mauritian governments has been to encourage the teaching of ancestral languages as part of the linguistic and cultural heritage of Mauritians. Besides English and French, taught throughout the primary and secondary curricula, Asian heritage languages are offered as optional languages in schools. Since 2012, Kreol is offered as an additional optional language in primary education alongside the Asian languages (Owadally, 2016). The official standard orthography (Grafilarmoni) was devised by linguists at the University of Mauritius in collaboration with the Mauritius Institute of Education (Hookoomsing, 2004). In 2018, Kreol was introduced in the first year of secondary education as an additional optional ancestral language and the present study provided an ideal opportunity to investigate the changing patterns of language use and attitudes of young Mauritians with a focus on Kreol in education.

The fieldwork study was carried out in August-September 2018 in secondary schools as a follow-up to two previous investigations completed each within a decade's interval in the last two decades (XXXX, 1998, 2011). The present investigation was designed to determine:

(i) if the changing patterns of language use and language choice of students in secondary schooling was consistent with results found a decade ago;

(ii) secondary school students' attitudes towards studying Kreol as another subject and as a medium of instruction for all subjects in school;

(iii) how the 2018 results compared with earlier fieldwork on attitudes towards Kreol in education.

In the following sections, a brief overview of the social history and the current language situation are given followed by the literature review and fieldwork methodology. The findings are compared with relevant results from previous research carried out by the author $(1998,2011)$. The conclusion explores implications for Kreol integrated in the education system and its role in shaping Mauritian identity.

\section{Social history: a brief overview}

The linguistic diversity on this small island of 1,865 square kilometres results from its colonial history: French occupation in the $18^{\text {th }}$ century and British in the $19^{\text {th }}$ until its independence. Under French occupation, slaves were imported mainly from the East coast of Africa and the island of Madagascar to work on sugar cane plantations to develop a sugar-based economy. Creole language in Mauritius is said to have been born 'in situ' through the interactions between the slaves and their French plantation owners in the first fifty years of colonisation (Corne, 1999: 164). 
One of the reasons why there is a stigma attached to the status of Creole languages is because of the social and historical conditions they were born in. Creole languages are often considered as bastardized and incorrect versions of their genetic parents (Sebba, 1997; Siegel, 1999; Coulmas, 2005), which in many cases are standard European languages associated with colonial expansion (French, English, German, Spanish, Portuguese). As such, they are perceived by the speakers themselves as having a lower status than their genetic parent. The relationship between Creole languages and their genetic parent is one of classic diglossia as defined by Ferguson (1959).

During the Napoleonic wars, France lost Mauritius to Great-Britain. Under British rule, waves of indentured labourers from India were sent to various parts of the British Empire to work on sugar plantations. Those who were shipped to Mauritius came mainly from North East India and their mother tongue was Bhojpuri. From 1834-1912, Mauritius imported the highest number of Indian immigrants (over 453,000) in comparison with other colonies (Biltoo, 2004: 179). There were also Chinese migrants from Hong-Kong and mainland China who emigrated to Mauritius during that time and whose main mother tongue was Hakka.

The arrival of the Indians and Chinese in Mauritius added Oriental multiculturalism and multilingualism (Hookoomsing, 2009) to the island with a whole range of Indian and Chinese languages to the already present European languages (French and English) and Creole. The multilingual situation in Mauritius resulting from its colonial history is complex described by Calvet (2015:2) as a 'patchwork linguistique' and 'bigarrure', where paradoxes prevail and predictions made by linguists have not occurred.

\section{A complex language situation}

The last population census carried out in 2011 listed twelve 'languages of forefathers' as currently spoken on the island. These were in alphabetical order: Arabic, Bhojpuri, Chinese Languages (Hakka, Cantonese and Mandarin), Kreol, English, French, Hindi, Marathi, Tamil, Telugu, Urdu, and 'Other and not stated'. Although Arabic was recorded in the census, it is in fact not a heritage language in Mauritius and its use is mainly confined to the education and religious domains. In the Mauritian context, the Asian heritage languages refer specifically to the following Indian languages -Bhojpuri, Gujarati, Hindi, Marathi, Urdu, Telugu and Tamil- and Chinese languages: Cantonese, Hakka and Mandarin. Since these languages were spoken by the first Indian and Chinese migrants, they are also referred to as language of forefathers or ancestral languages. The relationship between Hindi and Bhojpuri is one of classic diglossia where Bhojpuri has the lower status. Although English is the official language of state institutions, it is more a written than a spoken language in Mauritius. French, on the other hand, is frequently spoken in the workplace, media and education. The variety of French spoken in Mauritius is influenced by the other languages it comes in contact with on a daily basis such as English and Kreol, the characteristics of the speakers themselves, as well as norms from 
standard French (Baggioni \& de Robillard, 1990; de Robillard, 1993: 131). Nonetheless, with the increasing presence of standard French in daily media and Mauritians graduating from French universities, Baggioni and de Robillard predicted that Mauritian French would be a mixture aligned to standard French at a lexical level and less at the syntactic and phonological levels thus making 'un cocktail, suivant une alchimie difficile à définir d'avance' (Baggioni \& de Robillard 1990: 140). Ludwig et al. (2009:198) point out that Mauritian French is characterised by code-mixing from Kreol which differentiates it from standard French and that its speakers understand and accept this differentiation. In this study, French will mean the variety of French spoken in Mauritius as described above.

Kreol as the lingua franca of the island has seen its use in the home domain, media and government administration increasing since the 90s. Nevertheless, the relationship between French and Kreol is also one of diglossia with Kreol having a low status and French a high status. In addition, the growing shift to Kreol from Bhojpuri over the years has resulted in a non-classic diglossic relationship as described by Fishman (1967) between Kreol and Bhojpuri, where Bhojpuri has a lower status in addition to the classic BhojpuriHindi diglossia (Hookoomsing, 2009: 39).

\section{Language attitudes and language shift}

Attitudes towards languages are not easy to define, measure or predict, since they are multi-dimensional and can manifest themselves in a range of behaviours and subjective views (Edwards, 1982; Baker, 1992; Romaine, 1995; Garrett, Coupland, \& Williams, 2003). We would align with Garett's (2010, p. 20) general definition of an attitude which is 'an evaluative orientation to a social object of some sort whether it is language, or a new government policy, etc.'

In multilingual contexts, attitudes towards languages can derive from ideological beliefs of speakers, which are linked to their perceptions of language varieties, politics, economy and considerations of prestige and power (Woolard \& Schieffelin, 1994; Garrett et al., 2003; Coupland \& Bishop, 2007; Kircher, 2016). Such beliefs, either positive or negative, either conscious or unconscious, can contribute towards language change, language shift and/or attitude shift in a community.

Language shift is 'a process through which a particular community gradually abandons its original native language and goes over to speaking another one instead' (Trudgill, 1995: 175). It implies a situation of transitional bi/multilingualism that takes place over a long period of time. As the literature suggests, language shift is influenced by a variety of factors such as socioeconomic conditions in a society, gender, age of speakers (Chambers, 1992; Gal, 1979; Holmes, 1993), the education system and institutional support available (Appel \& Muysken, 2005; Clyne, 2005; Rubino, 2007). Other factors include roles played by migration (Muslim \& Brown, 2016; Perera, 2016), social networks and religion in the community (David, Naji, \& Kaur, 2003; Clyne \& Kipp, 2006), language choice of speakers (Mitchell et al, 2013, Coulmas, 2005) as well as associations between language and identity (Dorian, 1981; Baker, 1992; Fishman, 2006). 
Recent sociolinguistic studies in Mauritius have highlighted the complexity of the language ecology where negative and positive evaluations towards the same languages coexist, especially towards Kreol (Stein, 1982; Moorghen and Domingue, 1982; Hookoomsing, 1986; Author, 2012; 2014; Eriksen 1998; Miles, 2000; Biltoo, 2004; Rajah-Carrim, 2005; Eisenlohr 2007). Others include the dynamics of language contact and processes of language shift (Hookoomsing, 1987; 2009; Author 2011; Tirvassen, 2011) together with phenomena of code-switching and code-mixing in social interactions (de Robillard, 1993; Kriegel et al., 2009; Auckle and Barnes, 2011; Author , 2013; Auckle, 2015).

There are few studies on attitudes of Mauritians involved in the education sector towards Kreol in education (Rajah-Carrim, 2005; 2007; Sonck, 2005; Owodally and Unjore, 2013; Owadally, 2016; Harmon, 2014). The present study contributes towards closing this gap by focusing on language attitudes of students in secondary education towards Kreol as another subject of study and as medium of instruction given as Kreol has now been introduced at secondary level since 2018.

Most of the studies carried out on attitudes towards Kreol in education have highlighted mixed views concerning its adoption in the Mauritian education system. Rajah-Carrim (2007) found that those in favour of Kreol in the education system thought that Kreol had its place as an ancestral language and as a marker for identity for the Creole community. Those who were against considered the lack of an official standard and association with members of the Creole community who were socio-economically deprived as a disadvantage for Mauritius. Owadally and Unjore's (2013) investigated the use of Kreol in religious classes in Mauritian madrassahs. Although Kreol was used as a support language for the teaching of religious texts from the Koran written in standard Arabic, both teachers and parents voiced their preference for using French over Kreol. In their analysis of multilingualism in Mauritius since independence in 1968, Ramtohul and Eriksen (2018: 8) highlighted the paradoxical attitudes towards Kreol considered as a second-rated language both by members of the Creole community as well as those who are not from a Creole background.

Research conducted in some other Creole islands have highlighted the danger to multilingualism coming from those who are educated. Schwarz and Nick's (2018) study of official trilingualism (English, French, Seselwa or Seychellois Creole) in the Seychelles, revealed that teachers prefer English as the medium of instruction in schools. Professor Marie-Therese Choppy, in her key note presentation at the 2018 International Creole Studies Conference, University of the Seychelles, confirmed a shift from Seselwa towards English in the home domain with parents choosing to speak English to their children to increase their chances of success at school.

Oakes' (2013) study of attitudes towards Réunionnais by university students showed that although the use of the language was associated with Reunionese identity, it was mostly used in private spheres such as the home domain. More importantly, the students did not think that knowledge of Réunionnais would make 
them more employable. Oakes predicted (2013: 43) that the decline in passing on the language may result in a shift towards French in the future.

Mitchell et al. (2007) in their study of Saint Lucians living on the island of Saint Croix in the Caribbean found that social networks as well as language attitudes of parents at home were determining factors in the maintenance of Saint Lucian Creole.

Sallabank's (2013) investigation of language attitudes in Guernsey revealed that despite positive attitudes towards Guernesiais, viewed as a valued cultural heritage, the language was not being transmitted to younger generations and teaching in schools was not effective either. She recommended a revitalisation project where various stakeholders (2013: 344) could collaborate together to reverse the process of language loss.

\section{Methodology and Data Collection}

In a similar way to the two previous fieldwork studies, a multi-response questionnaire complemented by a face-to-face semi-structured interview were used in the present research to collect data in secondary schools. Secondary schools were chosen, since they are non-fee paying and are the best place to gather a representative sample of the younger generations.

A total sample of twelve secondary schools (three from each of the four educational zones) were visited from August and October 2018 during school hours as illustrated in figure 1 below. The schools were selected on a quota basis according to whether they were in urban or rural areas, single-sex or mixed, state or private. After securing formal authorisation from the Ministry of Education, the author contacted the school rectors in person to arrange for the school visits. Information sheets as well as participant consent forms were distributed to students' parents to ensure participants were informed about the aims of the research.

The method for collecting the data was similar in each school. The author visited the schools where she collected the data in person during school hours. In each school, the questionnaire was administered collectively to the students gathered in a classroom. Only those students' whose parents had signed the consent form participated in the study.

The procedure was the same for each school where the researcher was introduced either by the school rector or deputy rector as a Mauritian academic working in an Australian university researching multilingualism in younger Mauritians. The researcher ensured that the students understood the procedure for answering the multi-response questions written in English before reading them out loud in English and then translating them into French, one at a time, in the order in which they occurred, giving students sufficient time to write down their answers. All distributed questions were returned. A hundred and seventy nine students ( 75 boys and 104 girls) aged between 11 and 19 years completed the questionnaire and fifty-nine ( 24 boys and 35 girls) among 
them voluntarily agreed to participate in the follow-up interviews, thus allowing qualitative data to be compared with quantitative data.

The data collected from the questionnaire were pre-coded so that they could be computer-analysed. The questionnaire for collecting the data was in English and follow-up semi-structured interviews were conducted in the language of choice of students on topics of language use with various family members at home, language(s) considered as most important in Mauritius and what it meant to be Mauritian. The languages most frequently chosen by the students for the interview was French (30) followed by English (19) then Kreol (7) and a combination of French and English (3).

The questionnaire data were analysed by sociological variables of sex, place of residence (urban, rural), age group (younger group, older group) and level of family income (low, medium and high). Data from the interviews were transcribed verbatim. An analysis of the interview responses together with comments to the open questions were used to identify the main themes (Guest, Mac Queen, \& Namey, 2012:10-11), thus allowing qualitative data to be compared with quantitative data from the questionnaire to gain a better understanding of factors influencing language choice and language attitudes in the participants. For the scope of this article only responses relating to questions 9 on language(s) used at home, 14 and 15 (study of Kreol in school), 17 and 18 (Kreol as a subject and as a medium of instruction) will be dealt with.

\section{Results and Discussion}

\section{Language use in the home: a comparison over two decades}

An analysis of the census results (table 1 below) for language most frequently spoken in the home over the last two decades reveals a significant shift towards Kreol (from 69\% in 2000 to $86 \%$ in 2011) thus making Kreol the home language in Mauritius. The Asian heritage languages are steadily declining particularly Bhojpuri and the Chinese languages. As highlighted by Stein (1986: 276) and Hookoomsing (1993: 26), census data should be treated with caution as they tend to reveal general trends rather than development of specific languages. In addition, the censuses are completed by the head of the household whose answers are recorded as representing those of his/her family members. It may be recalled that the question asked in the present investigation was a multi-response one where participants were allowed to enter several languages spoken at home with different family members across generations (grand-parents, parents, siblings, uncle/aunts and cousins).

A comparison between the 2009 and 2018 fieldwork data reveals that the use of English has remained steady whilst the use of French has increased by $7 \%$. At the same time, the use of Kreol has slightly decreased (3\%). These results would seem to suggest a shift from Kreol to French in the home although further research is needed to determine if this trend is confirmed. 
The relatively high percentages for English and French have to be taken with caution. One possible explanation is that these languages are associated with high status and the study, which took place in a school environment where European languages have a prestige status. It should also be noted that the fact that the researcher introduced herself in English and in French as a native Mauritian who studied in Europe and is now working in an Australian university, may have prompted the respondents to overestimate their use of European languages.

Another more plausible explanation is by referring to the concept of language switching and language mixing as illustrated in Le Page and Tabouret-Keller (1985) in the case of multilingual speakers in creolophone settings who use different portions of language varieties in the same conversation. Kriegel et al (2009: 205) have highlighted two categories of language switching and language mixing that are common in Mauritius: urban and rural code-switching. While the alternation in urban regions is mainly between Kreol, French and English, in the rural areas speakers alternate between Bhojpuri, Creole and with English and French to a lesser extent. In their view 'the Mauritian polyglossia and the frequent instances of code hybridisation that characterise polyglossia play a major role in the identity of Mauritius' (Kriegel et al. 2019: 192).

The common occurrences of language-switching and language mixing on a daily basis was confirmed in the interviews since 25 respondents (42\%) claimed to speak 'un mélange' (a mixture) of Kreol, French and English at home. Our data reveal that English was mostly chosen for communicating on social media (Facebook, Instagram, Snapshat, Whatsapp) while French was the vehicular language used with teachers, friends and parents at home. The preference for French in daily interactions was corroborated in the language choice for the interviews with 51\% opting to speak in French, as indicated in the previous section. Although this study did not investigate the extent to which respondents alternated between each language, it would seem logical to think that participants entered all languages they spoke on a daily basis and that instances of alternation would be of an urban type as described by Kriegel et al. (2019) since all the participants were trilingual at least.

The current results revealed a further decline in the use of Asian heritage languages at home in the last decade. The data suggest a loss of Marathi as a home language since it does not appear to be spoken with any family member in comparison with the 2009 data. Telugu is another language, which is absent in the home although it was listed as an ancestral language by five respondents. These findings suggest a shift from Asian heritage languages towards Kreol and/or French thus corroborating findings by other scholars that these languages may be losing out to Kreol in the rural areas and to French in urban areas as education and social mobility increases (Biltoo, 2004; Hookoomsing, 2009; Kriegel et al. 2009; Tirvassen, 2011).

The higher percentage of Hindi (10\%) is unexpected given that Hindi is not a spoken language in Mauritius. However, Hindi was the Asian language most frequently studied in the present sample followed by Urdu, Tamil, Telugu and Chinese. The use of Bhojpuri as a language in the home has been steadily declining over 
the last decades as can be noted in table 2 below. Hookoomsing (2011: 45) suggested a Bhojpuri-Hindi shift that may be attributed to the impact of formal education sustained through the media and Bollywood in particular. Since in school students would be interacting in Hindi, in the same way as for English and French, it would be plausible to think that some students who study Hindi formally may also have listed Hindi as a language spoken at home, although they may not speak it at home. Indeed in the interviews, many students referred to Bhojpuri as Hindi and used both terminologies interchangeably. In the current sample, there were 36 participants who were studying Hindi as a third language in school.

It was proposed to include a question on family religion in the questionnaire to determine to what extent family religion was a factor in the study and/or maintenance of Asian heritage languages. However, the Ministry of Education advised against it, since association of religion with language was considered a sensitive issue. While this data was not available, implications about language, identity and loyalty towards ancestral languages cultures are discussed from the project data in the comparative analysis section and in the conclusion.

\begin{tabular}{|l|l|l|l|l|l|l|l|l|l|}
\hline Sample \% & Bhojpuri & Kreol & English & French & Hindi & Marathi & Tamil & Urdu & Chinese \\
\hline $\begin{array}{l}2000 \\
\text { census }\end{array}$ & 12.4 & 69.2 & 0.3 & 3.48 & 0.7 & 0.16 & 0.31 & 0.15 & 6.1 \\
\hline $\begin{array}{l}2009 \\
\text { Fieldwork } \\
\text { Study }\end{array}$ & 6.5 & 87.5 & 27.6 & 39.2 & 8.1 & 1.8 & 3 & 3 & $0 *$ \\
\hline $\begin{array}{l}2011 \\
\text { Census }\end{array}$ & 5.4 & 86 & 0.48 & 4.25 & 0.72 & 0.04 & 0.09 & 0.06 & 0.27 \\
\hline $\begin{array}{l}2018 \\
\text { Fieldwork } \\
\text { Study }\end{array}$ & 5 & 85 & 28 & 46 & 10 & 0 & 1 & 1 & 1 \\
\hline
\end{tabular}

1. Languages spoken in the home: a comparison over the last two decades

*There were no respondents who spoke a Chinese language at home in the 2009 sample

An analysis of language combinations spoken with family members at home (figure 1 below) revealed that Kreol was frequently spoken with all family members (37\%) closely followed by a trilingual combination of English, French and Kreol (32\%) and a bilingual combination of English and French (8\%). The data showed that Asian heritage languages were mostly spoken with the grand-parents' with Bhojpuri, Hindi and Urdu being the most common ones. These results corroborate findings from earlier studies (author, 2011: 426) that, as expected, it is the grand-parents' generations who are maintaining the heritage languages in the home domain. 


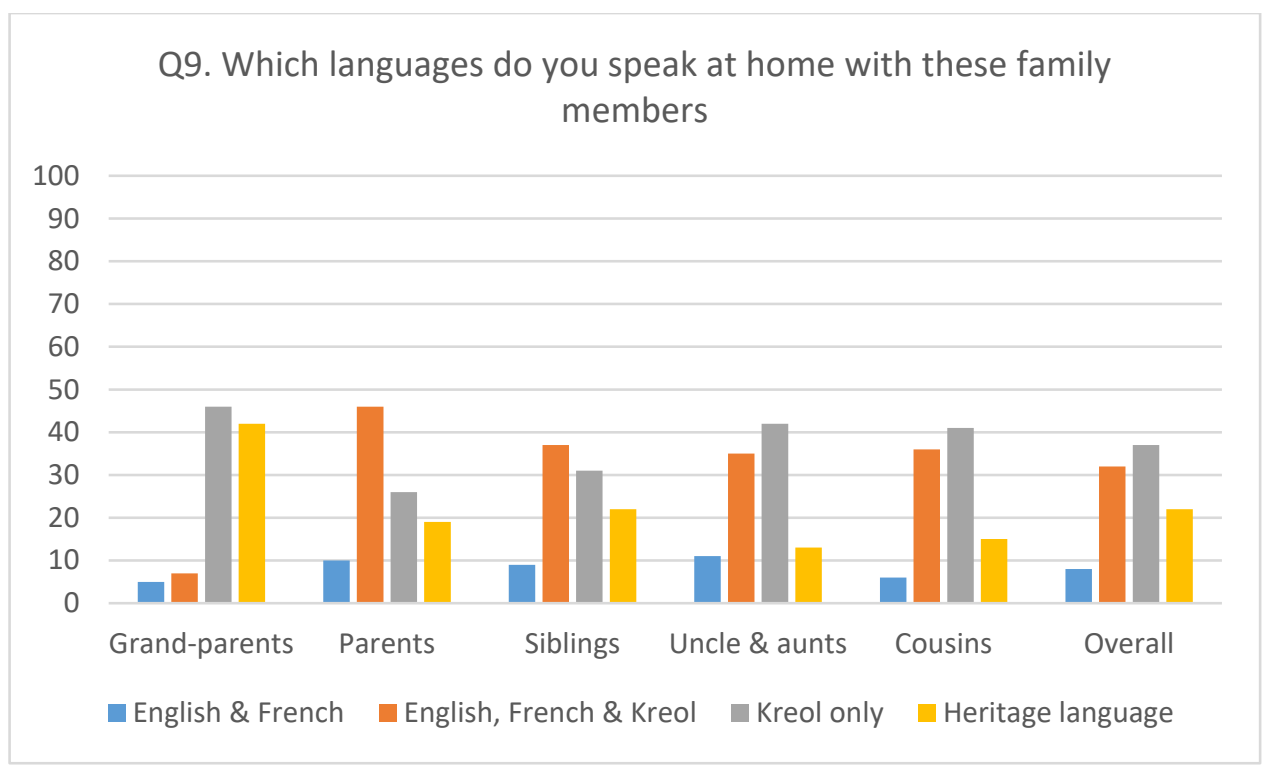

Figure 1 Language combinations spoken at home

A statistical analysis was conducted to examine whether social variables of gender (boy/girl), place of residence (urban/rural), parents' socio-economic status (low, medium, high) and age group (younger grades 7-9; older grades 10-13) were statistically significant. A Pearson chi-square test revealed that gender $\chi 2(1, N$ $=179)=.050, P>.05)$, place of residence $\chi 2(1, \mathrm{~N}=179)=0.75, P>.05)$ and socioeconomic status of parents $\chi 2(1, N=179)=.040, P>.05)$ were not significant factors for predicting language use at home.

Although the difference was not statistically significant in the language choice by gender variable, the results showed a higher level of use of Kreol for boys with parents and siblings while there was a higher use of heritage languages with grand-parents for girls. Girls also seemed to favour English and French more than the boys did. Further studies in the future need to be carried out to confirm these trends.

Students from lower socioeconomic backgrounds tend to make higher use of Kreol at home while students from a medium and high socioeconomic backgrounds use a higher combination of English, French and Kreol together with ancestral languages. Here again, the differences were not significant.

Language use by place of residence showed a slightly higher use of ancestral languages in the urban areas and a higher use of trilingual combination in the rural areas while the use of Kreol was similar in both places of residences. The results would seem to suggest a shift from ancestral languages towards Kreol, French and English in the rural areas. Here also since the differences were not statistically significant, further studies in are needed to investigate if the continuing shift from Asian ancestral languages has resulted in their loss and replacement by Kreol and French.

There was however a significant relationship between age group and language choice at home, as revealed by the Chi-squared test of contingencies $\chi 2(1, n=179)=4.96, P<.05)$. It was the younger students who 
claim to use Kreol more frequently than their older counterparts thus confirming that as the students get older and are more educated, they tend to make more use of European languages.

Findings revealed a higher use of heritage languages for older participants with the grand-parents generation than younger participants (table 2 below). It was the older group who claimed using a higher combination of English, French and Kreol with family members except with grand-parents. The higher use of trilingual combinations can be explained by the fact that the study took place during the third term when students in grades 11 and 13 were busy preparing for their School Certificate (SC) and the Higher School Certificate (HSC) examinations. These students would be more likely to interact in all three languages on a daily basis at school, during private tuitions and at home with a focus to prepare efficiently for these examinations set in the English language by the University of Cambridge International Examinations jointly with the Mauritius Examinations Syndicate (Maulloo and Naugah, 2017: 6).

\begin{tabular}{|l|l|l|l|l|l|l|l|l|l|l|l|l|l|}
\hline Language \% & \multicolumn{2}{l|l|}{$\begin{array}{l}\text { Grand- } \\
\text { parents }\end{array}$} & \multicolumn{2}{l|l}{ Parents } & \multicolumn{2}{l|}{ Siblings } & \multicolumn{2}{l|}{$\begin{array}{l}\text { Uncle \& } \\
\text { aunts }\end{array}$} \\
\hline $\begin{array}{l}\text { Younger group(Y) } \\
\text { Grades 7-9 } \\
\text { Older group(O) } \\
\text { Grades 10-13 }\end{array}$ & $\mathrm{Y}$ & $\mathrm{O}$ & $\mathrm{Y}$ & $\mathrm{O}$ & $\mathrm{Y}$ & $\mathrm{O}$ & $\mathrm{Y}$ & $\mathrm{O}$ & $\mathrm{Y}$ & $\mathrm{O}$ & $\mathrm{Y}$ & $\mathrm{O}$ \\
\hline English \& French & 8 & 2 & 14 & 8 & 11 & 9 & 13 & 10 & 6 & 8 & 10 & 7 \\
\hline $\begin{array}{l}\text { English, French \& } \\
\text { Kreol }\end{array}$ & 3 & 1 & 38 & 46 & 31 & 42 & 26 & 42 & 26 & 46 & 25 & 35 \\
\hline Kreol only & 47 & 51 & 27 & 25 & 34 & 27 & 48 & 36 & 49 & 35 & 41 & 31 \\
\hline Heritage language & 33 & 59 & 22 & 21 & 24 & 21 & 14 & 12 & 19 & 11 & 22 & 25 \\
\hline
\end{tabular}

2. Language combinations spoken at home by age group

\section{Attitudes towards Kreol in education}

From January 2018, Kreol is offered in secondary schools at grade 7 only although not in every secondary school. While at the primary level a minimum of 5 enrolments is necessary for Kreol to be taught as a heritage language, at the secondary level, Kreol was being taught on an ad hoc basis because of a lack of trained teachers according to Kreol teacher trainer Dr Rughoonundun-Chellapermal (International Creole Studies Conference, University of the Seychelles, 31 October 2018).

The latest reform in the education system carried out in 2017 replaced the Certificate for Primary Education (CPE) deemed too competitive, elitist and unequitable by a Primary School Achievement Certificate (PSAC). The grades at the PSAC determine entry to regional secondary schools. This reform also made the first nine years of schooling (grades 1 to 9) compulsory with students having to take the National Certificate of Education at the end of grade 9 (http://ministryeducation.govmu.org/English/educationsector/nys/Documents/9yearSchooling Brochure.pdf). The first 
intake of the national test will be in 2020. Students will be assessed in three compulsory subjects (English, Maths and French) and will have to choose four electives from Languages, Science, Technical Studies and Social Sciences subjects. The academic results of the test will determine progress to either an upper secondary 'star' or academic college or a technical and vocational institution (https://defimedia.info/nineyear-continuous-basic-education-what-are-major-changes-brought-system).

Question 14 of our investigation asked students if Kreol was taught in their schools and in question 15, students had to indicate if they were studying Kreol. Results (figure 2 below) showed that amongst the twelve schools that were visited there were four schools where Kreol was offered in grade 7 ( 2 boys and 2 girls schools). Forty-six respondents reported that Kreol was available in their school amongst whom eleven were studying the language as their ancestral language. Although numbers may seem small at this stage, it would be interesting to undertake further study in the near future when Kreol becomes more available at secondary level to evaluate motivations for learning Kreol and its impact in enhancing learning in other subjects.

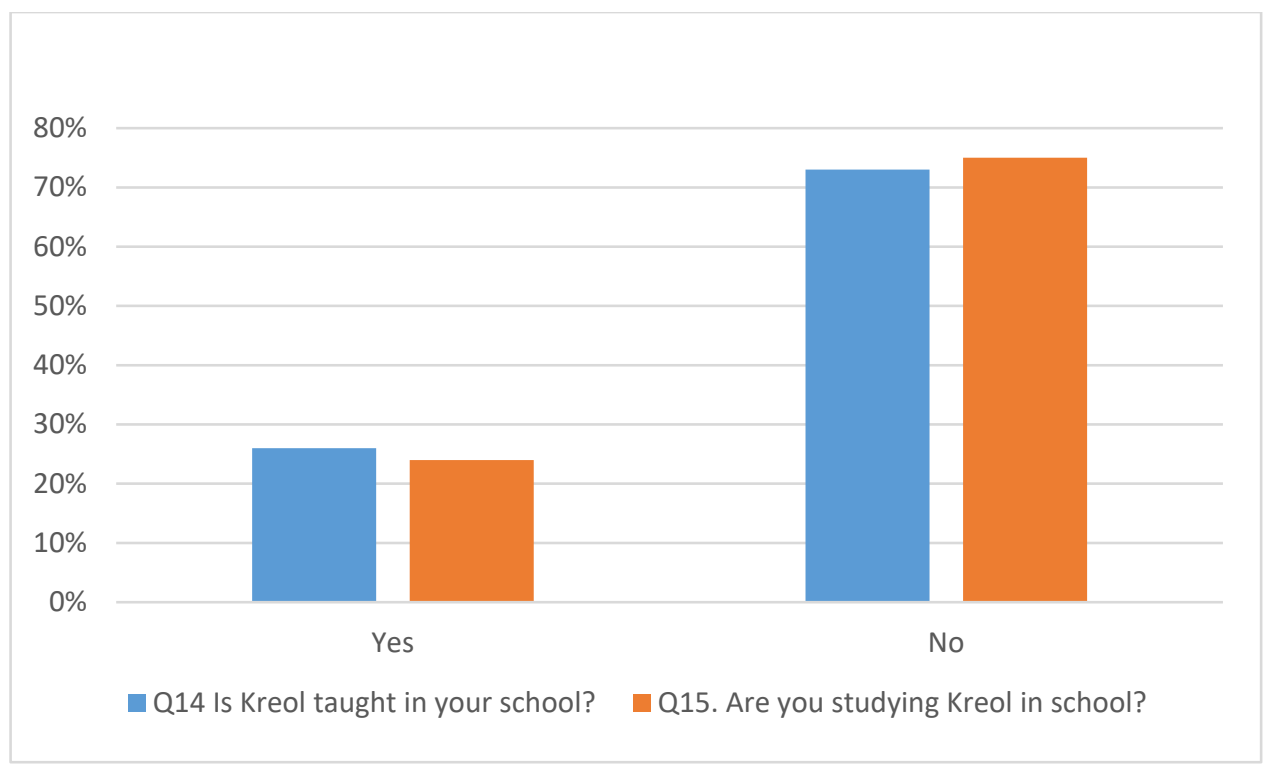

Figure $2 \mathrm{Kreol}$ in school

Question 17 was intended to find out if students were in favour of studying Kreol as another subject and question 18 elicited responses to having all subjects taught in Kreol in school. A greater number (Figure 3 below) were in favour of studying Kreol as a subject (47\%) than having the curriculum taught in Kreol (33\%). These questions were left open for participants to express their personal views on the questions. 


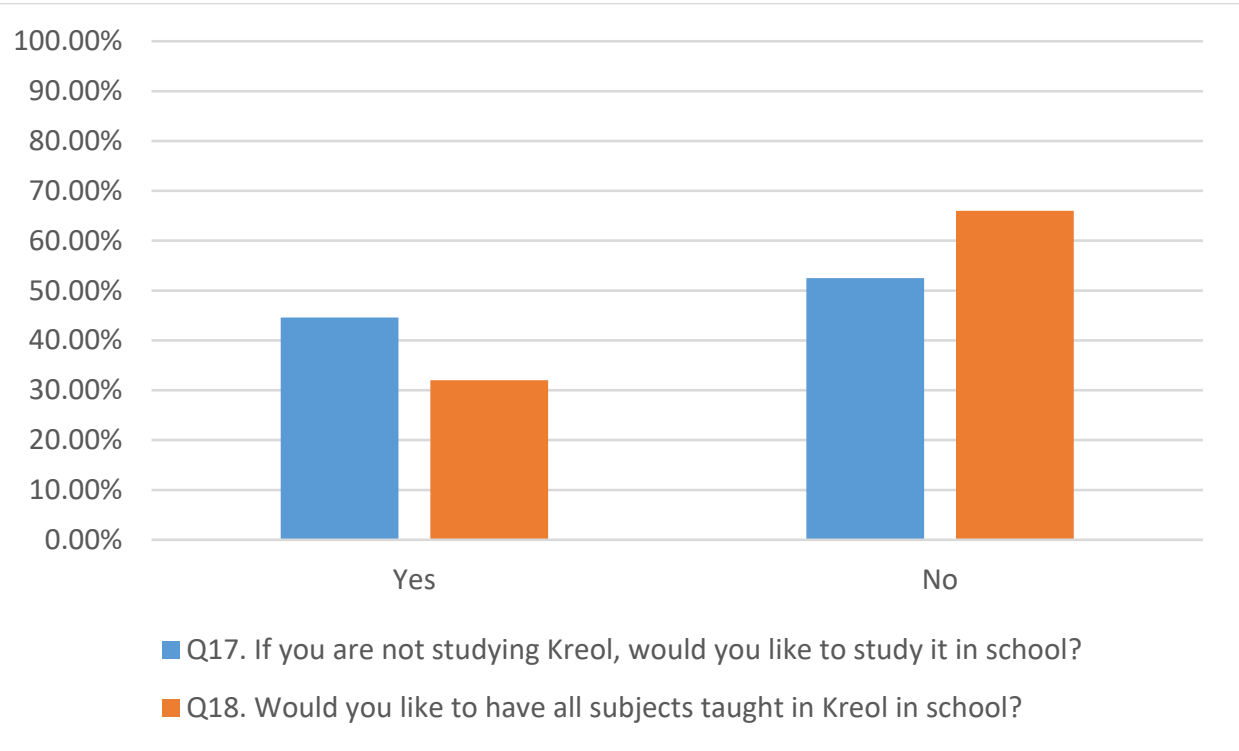

Figure 3. Kreol as a school subject and as medium of instruction

An analysis of the qualitative data revealed positive as well as negative attitudes towards Kreol in education. The negative views included that Kreol as 'a derivative of French' that 'will confuse me with my studies'. Other stronger reasons illustrated stigmas still attached to the language as 'it is disgusting to speak to the teacher in Kreol'. Other negative opinions highlighted the feeling of insularity associated with Kreol since 'English and French are important languages and can be used internationally compared to creole [sic]'.

Those in favour of Kreol as a school subject explained that they 'would be able to understand better the subjects since the majority speak Kreol in real life', and that 'it would be easier to give our answers during exams'. Others views were that Kreol as another subject would provide 'a more diverse choice' and an opportunity 'to know how to write it'. Some other reasons clearly relate to a national identity based on the Creole language as the language of Mauritius, since 'Kreol is my mother tongue and part of our culture' and if 'we stay in Mauritius we need to know how to speak Kreol to communicate'.

\section{A comparative analysis with results from the 1990s on Kreol in education}

The previous study investigating attitudes towards Kreol in education was carried out two decades ago (Author, 1998). It involved 200 pupils (102 boys and 98 girls) from a representative sample of the secondary school population and the methodology for data collection and analysis was similar to the present one. Participants were asked whether they would like to learn Kreol in school, have Kreol as a medium of instruction and have Kreol as the main language in Mauritius. As a detailed analysis of the results for this previous study has already been carried only the relevant data will be mentioned here.

In the 1998 data (figure 4 below) the majority of the respondents were against learning Kreol in school (78\%) and having it as the medium of instruction (75\%). Two thirds of the sample (66\%) were against having Kreol as 
the only main language in Mauritius thus suggesting a multilingual preference that would include English and French as the main languages of the island.

A comparison between both sets of data suggests a shift in language attitudes and beliefs amongst the younger generations. Attitudes towards Kreol in education in 2018 show a positive shift, since nearly $50 \%$ of the students (figure 3) were in favour of studying it as another subject. Although the majority of participants in both samples are against the adoption of Kreol as the medium of instruction, there is a slightly higher number (32\%) in favour in comparison with $24 \%$ two decades ago (Author 1998: 336 ).

As pointed out in the introduction section, the focus of this project was to find out attitudes towards Kreol, taught formally in secondary schools since 2018 in comparison with two decades ago when it was not so. Nonetheless, data obtained for question 13 , which asked respondents if they were studying an ancestral language can shed some light on aspirations and factors informing the study of heritage languages in school. Quantitative data revealed that $35 \%$ of the students in the sample were studying an Asian heritage language. Hindi was the most popular studied by $20 \%$, followed by Urdu (7.8\%), Arabic (2.1\%), Mandarin (1.7\%), Tamil (1.7\%), Telugu (1.1\%) and Marathi (0.5\%).

Qualitative data revealed that factors affecting heritage language choice were varied and ranged from education, culture, having studied the language in primary school and functionality of international languages, particularly in the case of Mandarin and Hindi. Religion as a factor influencing the study of ancestral languages was claimed by a small minority in the case of Hindi (4\%), Arabic (2\%) and Tamil (0.5\%). Furthermore, data on language preference highlighted that for the majority of the sample, perceptions of European languages were associated with academic success and social mobility, which far outweighed the benefits of learning one's ancestral language. Our results support Eriksen's (2018: 9) view that there is, in this section of the population, a sense of belonging to the Mauritian nation where ethnicity may be competing with other forces such as globalisation, increased exposure to social and global media, consumer culture and tourism. 


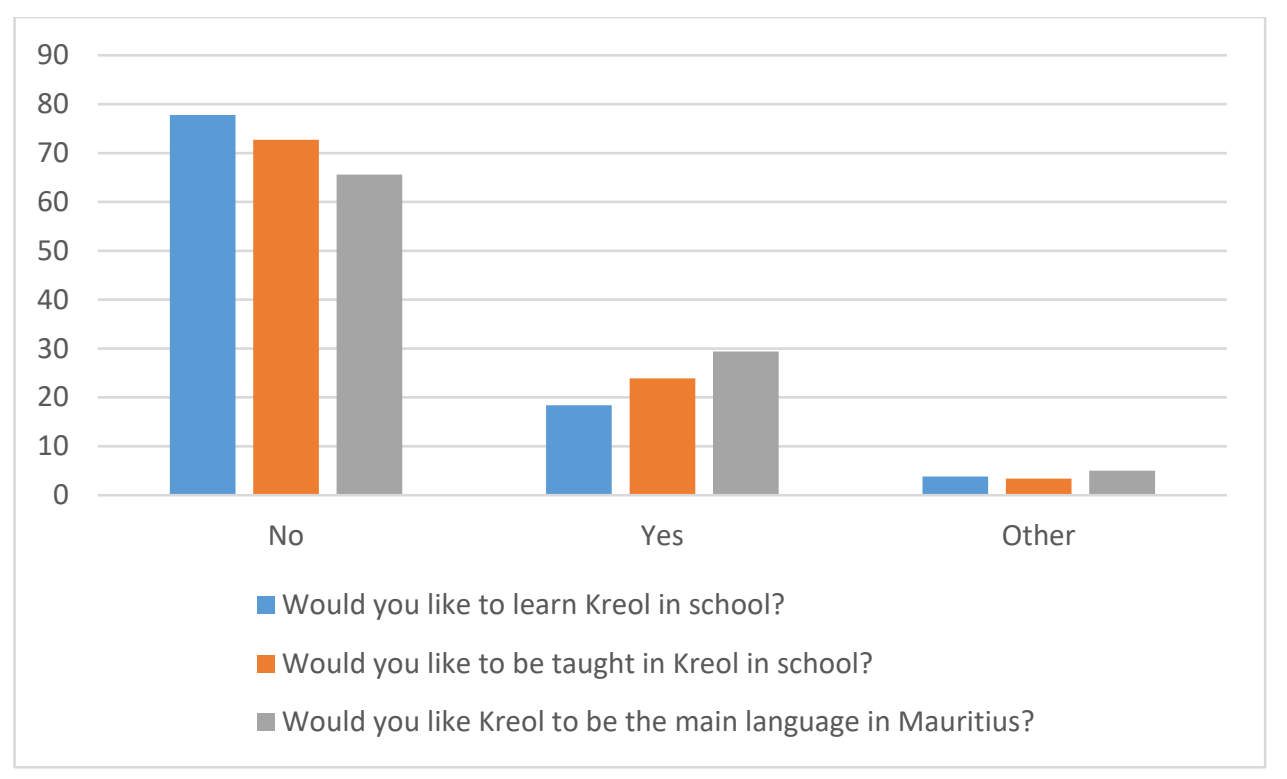

Figure 4. Kreol in school in 1998 sample

\section{Conclusion}

This article analysed results from a fieldwork study carried out in secondary schools to investigate how language use trends are evolving amongst the younger generations, with an emphasis on attitudes towards Kreol in education as it is being taught in secondary schools since 2018.

Data on patterns of language use in the home illustrate a steady decline of Asian ancestral languages and confirm the shift towards Kreol and French that was highlighted in previous fieldwork. The statistical analysis of language use in the home domain by social variables of gender, place of residence and socio-economic status of parents did not show great overall differences although there were some trends which were noted. The low percentages in the use of ancestral languages in the home domain would suggest that when the current parent generations become grand-parents themselves they may not pass on their heritage language to their grand-children. Consequently, continuing language shift may result in loss leaving the school as the only place where Asian languages would be learnt.

Findings from the open questions and interviews suggest an attitude shift towards acceptance of Kreol as a subject in school and as a medium of instruction in comparison with results from two decades ago. One student in two was in favour of studying Kreol as another subject and one student in three perceived Kreol as the medium of instruction positively. Although negative attitudes still persist towards the adoption of Kreol in school, overall attitudes reveal a pragmatic approach to languages present in the Mauritian environment and corroborate findings of previous studies (Author, 1998, 2011). The significant shift noted in the 2018 sample was that young Mauritians in education appear to be more accepting of and have integrated Kreol in their daily lives. 
Our data also highlighted a hierarchy between European, Kreol and Asian languages, where English \& French are preferred and have more prestige than Kreol and Asian languages. The attitudes illustrate a situation of multiple diglossias and linguistic paradoxes as described earlier. Indeed European languages have a higher status and are associated with academic success, good employment prospects and social and linguistic mobility. In comparison, Kreol is valued as the mother tongue understood and spoken by all Mauritians whereas Asian heritage languages are associated with cultural heritage of ancestors even though they are not used in daily interactions. The negative attitudes towards Kreol in education continue to persist despite its adoption in school and reflect long-standing attitudes of political discourse and beliefs as noted by RajahCarrim (2007) and Owadally and Unjore (2013).

Nonetheless, the results point to other underlying factors associated with the Creole language, ethnic and religious identities, and politics, which cannot be overlooked as they seem to be profoundly rooted in Mauritian society. Since it was not possible to include a question about family religion in the questionnaire (see page 9), a few remarks can be made by way of hypothesis.

The fact that I was advised to omit the question on family religion suggests that the Mauritian government appears to be concerned about family religion being investigated as a social parameter that can impact on the language use and language choice of younger generations. Why is religion deemed to be a sensitive issue? Is the promotion of multiculturalism through education via teaching of ancestral languages and cultures without mentioning religion a way to bypass a 'tendency to subsume religion under ethnicity' (Hanoomanjee 2000: 219 quoted in Biltoo, 2004: 397) and thus avoid inter-community tensions? Or is it that the education sector feels responsible for being unable to reconcile what Tirvassen and Ramasawmy (2017: 45) refer to as 'the identity crisis with regards to the teaching of Oriental languages'?

As history has shown, although politics and language may be closely linked in the multilingual and multicultural context of Mauritius, parents' voice in their offspring education cannot be legislated. In 1995, the disastrous political consequence resulting in the vote of no-confidence and general elections following the government's attempt to legislate language education by giving equal weighting to French and the ancestral languages in the certificate of Primary education (Author, 1998: 382), has shown that the main concern for parents, irrespective of their ethnolinguistic group, was with the educational and employment prospects and not with their heritage languages nor with politicians trying to capitalise on these languages for gaining votes (Eriksen, 2018: 8-9). Results from fieldwork in 2009 (Author, 2011) confirmed that in spite of education policies favouring the study of Asian heritage languages in secondary schools, they had not resulted in encouraging students to study them. Moreover, their loss in the home domain was being compensated for by Kreol and French as the first languages of the home. 
Although language, identity and ethnicity were not the focus in this article, our data show that acceptance of Kreol as the mother tongue of Mauritians as well as a symbol of Mauritian national identity is a reality for these young multilingual Mauritians from various ethnolinguistic and religious backgrounds. Further research is needed in the future, when Kreol will have been fully introduced across the first nine years of compulsory schooling, to evaluate the contribution of formal education in promoting Kreol as a language associated with a desirable marker of national identity and having official status alongside English and French.

\section{Acknowledgements}

I would like to thank the Mauritian Ministry of Education for providing me with formal authorisation to carry out my study in schools and to school rectors and teachers who assisted me during my fieldwork. I am also grateful to the students who participated in this study during their school hours. Last but not least, I thank Gaetano Rando and Michael Matthias for their comments on earlier drafts of this article.

\section{References}

Appel, R. and Muysken, P. 2005. Language Contact and Bilingualism. Amsterdam: Amsterdam University Press.

Auckle, T. and L. Barnes. 2011. Code switching, language mixing and fused lects: Emerging trends in multilingual Mauritius. Language Matters 42(1): 104-125.

Auckle, T. 2015. Code Switching, Language Mixing and Fused Lects: Language alternation phenomena in multilingual Mauritius. Unpublished DLitt and Phil Thesis. Pretoria: University of South Africa.

Baker, P. and Corne, C. 1982. Isle de France Creole: affinities and origins. Ann Arbor: Karoma.

Baker, C. 1992. Attitudes and Language. Clevedon: Multilingual Matters.

Biltoo, A.K. 2004. Language maintenance and language shift in Mauritius: A Sociolinguistic investigation into the language practices of Bhojpurias. PhD thesis. University of York, UK.

Bissoonauth, A. 1998. Language use, language choice and language attitudes among young Mauritian adolescents in secondary education. PhD thesis, University of Nottingham.

Bissoonauth, A. 2011. Language shift and maintenance in multilingual Mauritius: the case of Indian ancestral languages, Journal of Multilingual and Multicultural Development, 32:5, 421-434.

Bissoonauth, A. 2012. Attitudes towards English in Mauritius: linguistic paradox or cultural pragmatism? In Crafting Identities, Remapping Nationalities: The English-Speaking World in the Age of Globalization, Trevor edited by T. Harris and C. Coquet-Mokoko, 87-102, Newcastle upon Tyne: Cambridge Scholars Publishing.

Bissoonauth, A. 2013. Hybridation linguistique et alternance codique chez les adolescents Mauriciens de niveau secondaire: une analyse sociolinguistique. In Contacts de langues, langues en contact, Revue du 
Centre Linguistique d'Aix-en-Provence, ed. S. Kriegel and D. Véronique, no. 24: 139-153. Aix Marseille : Presses Universitaires de Provence.

Bissoonauth, A. 2014. Language attitudes of Mauritian youth in secondary education: some preliminary results. Actes du XIII6 colloque du Comité International des Etudes Créoles (Maurice, 5-9 novembre 2012), ed. A. Carpooran, 247-266. Vacoas : Editions le Printemps, Ltée.

Baggioni, D and de Robillard, D. 1990. Ile Maurice : une francophonie paradoxale. Paris : L'Harmattan.

Calvet, J. 2015. Préface. In Ecrits sur les langues, ed. I. Asgarally. Port-Louis, Super Printing Co Ltd.

Chambers, Y.K. 1992. Linguistic correlates of gender and sex. English World Wide, 13 (2): 173-218.

Clyne, M. 2005. Australia's language potential. Sydney: University of New South Wales Press Ltd.

Clyne M., and Kipp, S. 2006. Australia's community languages. International Journal of the Sociology of Language, 180: 7-21.

Coulmas, F. 2005. Sociolinguistics. The study of speakers' choices. Cambridge. Cambridge University Press. 2008 edition.

Coupland, N., and Bishop, H. 2007. Ideologised values for British accents. Journal of Sociolinguistics, 11 (1): 7493.

Corne, C. 1999. From French to Creole. The development of new vernaculars in the French colonial world. Westminster Creolistics series 5. London: University of Westminster Press.

David, M.K., Naji, M.H., and Kaur, S. 2003. Language maintenance or language shift among the Punjabi Sikh community in Malaysia? International Journal of the Sociology of Language: 1-24.

Dorian, N. 1981. Language loss and maintenance in language contact situations. In The loss of language skills. Rowley, edited by R.D. Lambert and B.F. Freed, MA: Newbury House Publishers.

Edwards, J. 1982. Language attitudes and their implications among English speakers. In Attitudes towards language variation. Social and Applied Contexts edited by E.B. Ryan and H. Giles, 20-33, London: Arnold.

Eriksen, T.H. 1998. Common Denominators: Ethnicity, Nation-building and Compromise in Mauritius. Oxford, New-York: Berg.

Eisenlohr, P. 2007. Creole Publics: Language, Cultural Citizenship, and the Spread of the Nation in Mauritius. Comparative Studies in Society and History 49 (4): 968-996.

Ferguson, C.A. 1959. 'Diglossia'. Word 15: 325-340.

Fishman, J, A. 1967. Bilingualism with and without diglossia; diglossia with and without bilingualism. Journal of Social Issues 23: 29-38.

Fishman, J.A. 2006. Language maintenance, language shift and reversing language shift. In The Handbook of bilingualism, edited by T.K. Bhatia, C. William and C. Ritchie, Malden, MA: Blackwell.

Gal, S. 1979. Language shift. New York: Academic Press. 
Garrett, P. 2010. Language attitudes. Cambridge: Cambridge University Press.

Garrett, P., Coupland, N., \& Williams, A. 2003. Investigating language attitudes. Social meanings of dialect, ethnicity and performance. Cardiff: University of Wales Press.

Guest, G., Mac Queen, K.M. and Namey, E.E. 2012. Applied thematic analysis. Los Angeles: Thousand Oakes, Sage Publications.

Hanoomanjee, E. 2000. Ethnicity, social policy and mobility. In S. Nirsimloo-Gayan (ed.) Towards the Making of a Multicultural Society. Moka, Mauritius: Mahatma Gandhi Institute.

Harmon, J. 2014. Heritage Language and Identity Construction: A Critical Ethnography of Kreol Morisien as an optional language in primary education within the Republic of Mauritius. PhD thesis, University of the Western Cape.

Hookoomsing, V.Y. 2004. Grafi-larmoni: A harmonised writing system for the Mauritian Creole language. Le Réduit : University of Mauritius Press.

Hookoomsing, V. Y. 1986. Langue et identité ethnique : Les langues ancestrales à Maurice, Journal of Mauritian Studies, 1, 2, 117-137.

Hookoomsing, V.Y. 1993. L'île Maurice et ses langues. In Revue du Livre : Afrique, Caraïbes, Océan indien. Littérature mauricienne. Notre Librairie 114, 26-32. Juillet-Septembre 1993. C.L.E.F. Paris.

Hookoomsing, V. 2009. Language Loss, Language maintenance. The case of Bhojpuri and Hindi in Mauritius. The Indian Diaspora: 1-16.

Kircher, R. 2016. Language attitudes among adolescents in Montreal: Potential lessons for language planning in Québec. Nottingham French Studies, 55(2), 239-259.

Kriegel, S., Ludwig, R and Henri, F (2009) Les rapports entre créole et bhojpouri à Maurice : Contacts de langues et actes identitaires. In Hookoomsing Vinesh. Y, Ralph Ludwig, and Burkhard Schnepel, B. (eds). Multiple Identities in Action. Mauritius and Some Antillean Parallelisms : 203-253. Peter Lang. Frankfurt. Kriegel, S., Ludwig, R and Salzmann, T. 2019. Reflections on Discourse Ecology and Language Contact: the Crucial Role of Some Scalar Terms. In Ludwig, Ralph, Peter Mühlhäusler, and Steve Pagel. (eds). Linguistic Ecology and Language Contact. Cambridge: Cambridge University Press.

Le Page, R.B and Tabouret-Keller, A. 1985. Acts of Identity. Cambridge: Cambridge University Press. Maulloo, A.K., and Naugah, B.J. 2017. Upper secondary education in Mauritius: a case study. https://royalsociety.org/ $/$ media/policy/topics/educationskills/Broadening\%20the\%20curriculum/mauritius-case-study.pdf (accessed February 28, 2019). 
Ministry of Education and Human Resources, Tertiary Education and Scientific Research. The Nine year Continuous Basic Education. http://ministry-

education.govmu.org/English/educationsector/nys/Documents/Presentation PRESS NN 19August2015pdf. pdf (accessed November 24, 2018)

'Nine-Year Continuous Basic Education: What are the major changes brought to the system?' https://defimedia.info/nine-year-continuous-basic-education-what-are-major-changes-brought-system (accessed August 7, 2018).

Mitchell, E., Gonzalez-Lopez, C., and Pierre, J.O .2007. French-Lexifier Creoles on Saint Croix: Language Choice and Attitudes towards St. Lucian, Dominican and Haitian Creole. Torre: Revista de la Universidad de Puerto Rico, 12 (46): 597-619.

Muslim, A.B. and Brown, J.R. 2016. Navigating between ethnic and religious identity: Heritage language maintenance among young Australians of Indonesian origin. Indonesian Journal of Applied Linguistics, 6(1): 145-154.

Mufwene, S. S and Vigouroux, C. B. 2008a. Colonization, Globalisation and language Vitality in Africa: An Introduction. In Globalization and Language Vitality: perspectives from Africa, edited by C.B. Vigouroux and S.S Mufwene. London: Continuum Press.

Mufwene, S.S. 2008b. Language Evolution: Contact, Competition and Change. London: Continuum Press.

Owadally, A.M.A and Unjore, S. 2013. Kreol at school: a case study of Mauritian Muslims' language and literacy ideologies. Journal of Multilingual and Multicultural Development, DOI:

10.1080/01434632.2013.763813.

Owadally, A.M.A .2016. Language, education and identities in plural Mauritius: a study of the Kreol, Hindi and Urdu Standard 1 textbooks. Language and Education, 28 (4): 319-339.

Perera, N. 2016. Tamil in the Temples-language and religious maintenance beyond the first generation. Multilingua 35(5): 535-559.

2011 Housing and Population census of Mauritius. Resident Population by language of forefathers and languages usually spoken at home. Table D10. Central Statistics Office, Port-Louis.

Rajah-Carrim, A. 2005. Language Use and Attitudes in Mauritius on the Basis of the 2000 Population Census. Journal of Multilingual and Multicultural Development, 26 (4) : 317-332.

Rajah-Carrim, A. 2007. Mauritian Creole and Language Attitudes in the Education System of Multiethnic and Multilingual Mauritius. Journal of Multilingual and Multicultural Development, 28 (1): 51-71.

Ramtohul R. and Eriksen, T.H. 2018. The Mauritian paradox. Fifty years of Development, Diversity and Democracy. Réduit : University of Mauritius Press. 
Robillard, de, D. 1993. L'Expansion du français à l'île Maurice : dynamisme stratificatoire, inhibitions ethniques. In Le français dans l'espace francophone. Description linguistique et sociolinguistique de la francophonie, edited by D. de Robillard, M. Beniamino and C. Bavoux, 129-145. Paris: Champion.

Romaine, S. 1995. Bilingualism. Oxford: Blackwell Publishers.

Rubino, A. 2007. Immigrant minorities: Australia. In Handbook of Language and communication: Diversity and Change, edited by M. Hellinger and A. Pauwels, New York: Mouton de Gruyter.

Rughoonandun-Chellapermal, N. 2018. 'L'apprentissage formel du créole en milieu scolaire mauricien: quel premier bilan en matière de littératie?' XVIe International Colloquuim of Creole Studies 'Creole worlds, Creole languages and Development: Educational, Cultural and Economic Challenges. University of the Seychelles 29 October-2 November 2018.

Schwarz, C.T.F and Nick, I.M. 2018. 'Mon respe tou lezot lalang!' a case study of native teacher attitudes towards Creole-mediated multilingual education in Seychelles'. Current Issues in Language Planning 19(2): 183-197.

Sebba, M. 1997. Contact Languages: Pidgins and Creoles. Basingstoke, Macmillan.

Siegel, J. 1999. Creoles and Minority Dialects in Education: An overview. Journal of Multilingual and Multicultural Development 20 (6): 508-531.

Stein, P. 1986. The value and problems of census data in languages : An evaluation of the language tables from 1983 population census of Mauritius. In J. Fishman et al (eds) The Fergusonian Impact. In Honor of Charles, A. Ferguson 2, 265-277. The Hague: Mouton de Gruyter.

Tirvassen, R and Ramasawmy, S.J. 2017. Deconstructing and reinventing the concept of multilingualism: A case study of the Mauritian sociolinguistic landscape. Stellenbosch Papers in Linguistics Plus, vol 51 : 41-59. Trudgill, P. 1995. Sociolinguistics: An introduction to language and society. London: Penguin books. Woolard, K. A., and Schieffelin, B. B. 1994. Language ideology. Annual Review of Anthropology 23: $55-82$. 